\title{
Penerapan Teknologi Rekayasa Konstruksi Wadah Budi Daya Rumput Laut Bagi Masyarakat di Pulau Nain
}

(Application of Engineering Technology for Construction of Seaweed Cultivation Containers for Communities in Nain Island)

Edwin L. A. Ngangi ${ }^{1}$, Reni L. Kreckhoff ${ }^{1}$, Grevo S. Gerung ${ }^{2}$

1) Staf Pengajar Program Studi Budidaya Perairan FPIK Unsrat, Manado

${ }^{2)}$ Staf Pengajar Program Studi Ilmu Kelautan FPIK Unsrat, Manado

Penulis Korespondensi : Edwin L.A. Ngangi, edwin.ngangi@unsrat.ac.id

The Higher Education Community Empowerment Program (PPMUPT) activity aimed to disseminate research results on design engineering and construction materials for verticultural cultivation of seaweed; Seed quality from seaweed cultivation centers in North Sulawesi; and Co-cultivation of seaweed and sea tilapia. The implementation partnered with the Nain Princess and Mekar Laut Groups, and was supported by the Nain Village Government. The three partners expressed their willingness and ability to work together in formulating and finding solutions to problems, as well as planning the implementation stages and all of these activities. In addition, partners continue to contribute throughout the activity. Formulation of problems with partners, are: Is there a technology that can minimize disease attacks on seaweed. The solution is in the form of: a. Engineering design and construction material for cultivation containers, b. Verticultural cultivation of engineering methods. The method applied was the classical and individual approach in the form of class lectures, demonstrations, and practices about the innovation of seaweed cultivation technology. The outputs of the PPMUPT activities were productive economic partners that have increased knowledge, skills, quality, quantity, and types of products. Participants were principally satisfied with this PPMUPT activity, and even $92.86 \%$ stated that they were very satisfied in participating in PPMUPT activities regarding the use of strings as ris ropes with seaweed verticulture methods.

Keywords: PPMUPT; Rumput laut; Vertikultur; Wadah budi daya

\section{PENDAHULUAN}

Kegiatan Program Pemberdayaan Masyarakat Unggulan Perguruan Tinggi (PPMUPT) ini merupakan kepedulian Fakultas Perikanan dan Ilmu Kelautan Universitas Sam Ratulangi terhadap masyarakat marjinal di kepulauan, dan sebagai suatu kontribusi pada program pemerintah dalam percepatan perekonomian desa. Penguatan kegiatan ini melalui aplikasi sains dan teknologi dari berbasis riset. Riset yang telah dilakukan Ngangi et al. (2018) tentang: Rekayasa desain dan material konstruksi wadah kultivasi rumput laut secara vertikultur guna peningkatan hasil produksi perikanan marikultur di pulaupulau kecil (Skim PSNI), Kreckhoff et al. (2018), topik: kualitas bibit dari sentrasentra budi daya rumput laut di Sulawesi Utara (Skim PDUPT), dan Gerung et al. 
(2018) tentang: Ko-kultivasi rumput laut Kappaphycus alvarezii dan ikan nila laut (Skim RTUU).

Potensi kemaritiman Pulau Nain belum diberdayakan secara optimal, serta kurangnya penguatan sains berupa aplikasi hasil riset dari perguruan tinggi. Selain itu, urgensi lainnya ialah kebutuhan akan pendampingan dan penatakelolaan pengembangan budi daya rumput laut sebagai upaya meningkatkan kemandirian dan kesejahteraan masyarakat Pulau Nain.

Pengembangan perikanan budi daya rumput laut di Pulau Nain sangat berpotensi saat dianalisis kondisi perairannya. Pulau ini mempunyai karakteristik perairan yang tenang dan terlindung dari ombak yang kuat, sehingga layak untuk lahan perikanan marikultur, dimana kelompok pembudidaya ikan (POKDAKAN) di Pulau Nain sebesar 90\% berkegiatan pada usaha budi daya rumput laut.

Penerapan hasil riset dalam kegiatan ini terdiri atas beberapa tahapan, yaitu: penyuluhan, pelatihan, dan pendampingan tentang Manajemen Perikanan Marikultur dengan konsep cara budi daya yang baik dengan melibatkan langsung kelompok mitra dalam mendesain dan konstruksi wadah budi daya rumput laut.

Tujuan khusus PPMUPT di Desa Nain ialah:

1) Memberikan solusi permasalahan budi daya rumput laut berbasis riset multidisiplin ilmu.

2) Mengaplikasikan hasil riset budi daya rumput laut yang sesuai dengan urgensi kebutuhan masyarakat.

3) Memberikan penguatan potensi masyarakat melalui aplikasi hasil riset unggulan.
Program PPMUPT ini akan menciptakan Desa Nain sebagai desa binaan mitra FPIK UNSRAT. Desa Nain akan memiliki keunggulan budi daya rumput laut sebagai icon dan penggerak utama pembangunan, sekaligus sebagai salah satu model sains-techno and tourism park perikanan marikultur konsep IMTA berbasis masyarakat.

Perumusan masalah prioritas dari hasil diskusi dengan mitra, terdiri atas:

1) Segi Produksi

a. Teknologi yang dapat meminimalisir serangan penyakit pada rumput laut.

b. Usaha budi daya rumput laut.

c. Meningkatkan produksi budi daya rumput laut.

Permasalahan manajemen produksi budi daya rumput laut yang dihadapi kelompok mitra ialah: pemilihan lokasi, pemilihan jenis rumput laut, desain dan konstruksi wadah, penanganan/penggunaan bibit, pengontrolan, dan perawatan wadah budi daya. Akar permasalahannya yaitu minimnya pengetahuan kelompok mitra tentang budi daya rumput laut yang baik, sehingga dibutuhkan penyuluhan, pelatihan, dan sampai pada pendampingan. Selain itu, dibutuhkan suatu sarana percontohan berupa demplot agar kelompok mitra dapat terus belajar dan meniru dalam manajemen budi daya rumput laut yang baik.

2) Manajemen Usaha

Mengelola usaha budi daya rumput laut untuk memberikan manfaat finansial. Akar permasalahan manajemen kelompok terletak pada pembagian tugas masingmasing kelompok yang berdampak pada pembagian hasil. Selain itu, dibutuhkan suatu bekal pengetahuan bagi kelompok mitra tentang pengelolaan keuangan mulai 
dari perencanaan, pelaksanaan, sampai pada pelaporan.

\section{METODE PELAKSANAAN}

Kebersihan wadah sangat ditentukan oleh material konstruksi yang digunakan. Selama ini, para pembudidaya menggunakan tali ris multifilament. Seratserat pada tali multifilament merupakan media bagi biota penempel untuk bertumbuh dan berkembang, serta debu air untuk menempel. Biota penempel dan debu air pada tali ris multifilament akan menyebar ke rumput laut yang dibudidayakan, sehingga mengganggu rumput laut yang dapat menyebabkan penyakit ice-ice. Selain itu, tali ris multifilament yang ditempeli biota epifit dan debu air sangat membutuhkan waktu untuk dibersihkan.

Solusinya mencari alternatif pengganti tali ris dengan menggunakan tali nilon monofilament (senar). Penggunaan tali ris nilon mon filament memberikan hasil yang positif, dimana biota dan debu air lebih sedikit yang menempel, dan mudah dibersihkan. Prevalensi penyakit ice-ice lebih rendah, dan pertumbuhan rumput laut lebih baik dibandingkan dengan penggunaan tali multifilament.

Pemecahan masalah kelompok mitra dilakukan melalui penyuluhan, pelatihan, dan pendampingan.

a. Penyuluhan dan Peragaan

Penyuluhan melalui ceramah untuk penyampaian hasil-hasil penelitian dan penerapannya di lapangan. Penyampaian materi bervariasi berupa konsep, gambar, video, dan animasi. Metode ini mudah diserap, dan dalam penyampaiannya lebih mudah serta dapat dilakukan dalam waktu yang singkat. Materi yang diberikan yakni: pemilihan lokasi yang layak, mendisain dan mengkonstruksi wadah budi daya, teknik budi daya.

Teknik budi daya langsung dipraktekkan di areal budi daya di Pulau Nain. Metode untuk teknik budi daya menunjukkan suatu prosedur dalam tahaptahap produksi: pemilihan bibit yang baik, penyiapan wadah budi daya, pemeliharaan, perawatan, dan pengawasan.

1) Ceramah dan praktek tentang pemilihan lahan

Kriteria lahan yang layak dinilai secara visual dan dari hasil riset yang sudah dilakukan. Lahan yang layak yaitu terlindung dari gelombang dan arus yang kuat. Parameter kualitas air berkriteria layak sampai sangat layak. Lahan yang dimanfaatkan berdekatan dengan sumber bibit.

2) Ceramah dan praktek tentang pemilihan bibit

Kriteria dan ciri-ciri bibit yang baik, yaitu: a) pertumbuhan cepat, b) performance menarik, c) Bibit terlihat segar dan berwarna cerah, d) Bebas dari penyakit, e) Bibit harus seragam dan tidak tercampur dengan jenis lain.

3) Ceramah dan praktek tentang kepadatan bibit

Kepadatan bibit untuk rumput laut tentang jarak antar bibit.

4) Ceramah dan praktek tentang masa pemeliharaan

Masa pemeliharaan sampai ukuran layak jual komoditas rumput laut hanya membutuhkan waktu 45 hari. Pembudidayaan harus dilakukan secara bertahap sehingga produksi dapat berkesinambungan.

Selain sebagai peserta dalam kelas dan praktek, kelompok mitra berpartisipasi dalam pengambilan serta penyediaan bibit rumput laut, penyediaan perahu, pemeliharaan, perawatan rumput laut dan 
wadahnya, serta melakukan pengawasan di lapangan selama program ini berlangsung.

$$
\text { Pada saat pemantauan }
$$

pertumbuhan, mitra juga membantu dalam mengukur dan mencatat produksi rumput laut. Selama program berlangsung, kelompok mitra Puteri Nain dan Mekar Laut diminta untuk menginformasikan atau mencatat kejadian-kejadian di lapangan, antara lain gangguan: alam, keamanan, hama, dan penyakit. Untuk itu setiap minggu ditunjuk koordinator kelompok peserta dalam kegiatan-kegiatan di atas.

Pre-test dan post-test dilakukan dengan cara wawancara yang berpedoman pada kuisioner yang tersedia.

\section{HASIL DAN PEMBAHASAN}

Rangkaian kegiatan yang dilakukan yaitu : 1) Sosialisasi pada pemerintah dan kelompok usaha rumput laut di Desa Nain, 2) Peninjauan lokasi budi daya rumput laut, 3) Kesepakatan lokasi pelaksanaan program penyuluhan, pelatihan, dan pendampingan, 4) Kesepakatan waktu dan struktur pelaksanaan program penyuluhan, pelatihan, dan pendampingan, 5) Pelaksanaan kegiatan penyuluhan dan pelatihan pengelolaan budi daya rumput laut.

Tahap persiapan dilakukan dengan menyiapkan media tanam berupa wadah budi daya rumput laut. Selanjutnya penyiapan bibit rumput laut untuk dibudidayakan. Penyiapan media tanam dan pembibitan dilakukan dua bulan sebelum kegiatan penyuluhan dan demonstrasi praktik dilakukan. Hal ini disebabkan ketersediaan bibit rumput laut yang masih kurang. Persiapan kuisioner yang digunakan saat pre-test dan post-test juga dilakukan pada tahap persiapan.
Selain itu, penyiapan materi penyuluhan juga dilakukan pada tahap ini.

Alih teknologi yang dilakukan pada kegiatan ini dimulai dengan penyuluhan. Penyuluhan dimaksudkan untuk memberikan pengetahuan mengenai : 1. Jenis-jenis rumput laut yang laku di pasar, 2. Material pembuatan konstruksi wadah budi daya, 3. Pemilihan bibit rumput laut yang baik, 4. Jenis, ukuran, dan pengikatan tali-temali, 5. Pengikatan bibit rumput laut, 6. Penambatan konstruksi wadah.

1) Pemeliharaan, panen, dan penanganan pasca panen rumput laut

Kegiatan penyuluhan disampaikan melalui paparan oral dan secara visual menggunakan power point, serta penayangan video mengenai pentingnya teknologi budi daya rumput laut yang baik dan benar. Ketiga pendekatan ini ditempuh untuk memudahkan adanya transfer ilmu pengetahuan mengenai jenis dan manfaat, serta teknologi budi daya rumput laut.

Pada saat penyuluhan dikembangkan kesempatan diskusi untuk memenuhi kebutuhan informasi bagi para peserta yaitu kelompok mitra Puteri Nain dan Mekar Laut yang akan diterapkan, serta peluang dan hambatan yang mungkin timbul saat melakukan kegiatan budi daya rumput laut. Para peserta cukup antusias dalam mengajukan beberapa pertanyaan terkait pemanfaatan dan pemeliharaan rumput laut.

Kegiatan alih teknologi selanjutnya adalah demonstrasi praktek langsung budi daya rumput laut. Kelompok mitra sebagai khalayak sasaran dilibatkan langsung dalam tahapan budi daya. Keberadaan lahan demplot menjadi wahana bagi para peserta untuk mencoba mempraktekkan dan 
menerapkan pengetahuan dan teknologi yang diperoleh dari penyuluhan dan pelatihan. Rumput laut yang dibudidayakan dari jenis $K$. alvrezii.

$$
\text { Rumput laut } K \text {. alvrezii }
$$
merupakan jenis rumput laut yang paling dibutuhkan pasar dunia karena kandungan karaginannya yang merupakan kandungan kappa-karaginan. Kegiatan demonstrasi praktik langsung meliputi penyiapan media tanam, penanaman bibit dan pemeliharaan rumput laut. Bibit rumput laut ditanam pada lahan dengan berat awal 100 gram, jarak antar tali ris 100 $\mathrm{cm}$.

Pemeliharaan rumput laut sangat mudah, yaitu hanya membutuhkn waktu perawatan setiap hari. Perawatan dilakukan dengan teknik menggoyanggoyangkan masing-masing tali ris selama beberapa saat. Pemantauan dilakukan untuk mengamati apabila ada rumput laut yang terserang penyakit white spot. Apabila ada yang terserang penyakit white spot, maka rumput laut tersebut langsung dipanen, kemudian digantikan dengan rumput laut yang sehat. Rumput laut yang dipanen karena terserang penyakit white spot dapat dikeringkan untuk dijual.

Umur panen rumput laut pada masa tanam selama 45 hari. Umur panen ini merupakan kualitas terbaik dari rumput laut karena produksi tertinggi kandungan karaginannya, dan merupakan produksi rumput laut yang memberikan keuntungan finansial yang paling menguntungkan. Rumput laut yang dipanen langsung dijemur untuk pengeringan, apabila matahari terik maka rumput laut akan kering selama 2 - 3 hari dengan kadar air $10 \%$.

Kebermanfaatan dan tingkat penerimaan peserta terhadap pengetahuan dan teknik yang diberikan dapat dievaluasi menggunakan metode pre test dan post test. Kegiatan pengabdian dikatakan berhasil dan bermanfaat jika (Modifikasi dari Hadi et al., 2017):

1. Peningkatan pengetahuan dan keterampilan peserta tentang pengenalan jenis-jenis rumput laut sebesar $>60 \%$

2. Peningkatan pengetahuan peserta tentang teknologi budi daya rumput laut sebesar $60 \%$

3. Peningkatan pengetahuan dan keterampilan peserta tentang teknologi panen dan pasca panen sebesar $>60 \%$

4. Peningkatan pengetahuan peserta tentang pentingnya rumput laut $>60 \%$.

Berdasarkan pre-test yang telah dilakukan, sebagian besar dari peserta penyuluhan pernah membudidayakan rumput laut. Meskipun demikian, pengetahuan mereka tentang materi penyuluhan masih terbatas, ditunjukkan dengan adanya jawaban yang masih keliru mengenai jenis rumput laut, pemilihan bibit, jarak tanam bibit, dan pemeliharaan sampai dengan pasca panen rumput laut. Oleh karenanya, kegiatan ini masih sangat relevan dengan kebutuhan para pembudidaya rumput laut.

Hasil post test yang telah dilakukan setelah adanya penyuluhan dan demplot menunjukkan terjadi peningkatan pengetahuan atau pemahaman peserta penyuluhan. Kegiatan pengabdian ini tergolong berhasil karena terjadi peningkatan pengetahuan di atas $60 \%$ dibandingkan saat belum dilakukannya alih teknologi dan demplot.

Berdasarkan hasil pre-test diketahui bahwa $85,71 \%$ peserta kegiatan PPMUPT belum pernah mengetahui 
tentang budi daya rumput laut menggunakan tali ris senar secara vertikultur, sedangkan $14,29 \%$ sudah pernah tahu tetapi belum menerapkannya (Gambar 1). Setelah kegiatan, berdasarkan post-test bahwa $100 \%$ dari seluruh peserta menyatakan sudah paham tentang budi daya rumput laut menggunakan tali ris senar secara vertikultur, bahkan 57\% menyatakan sangat paham (Gambar 2).

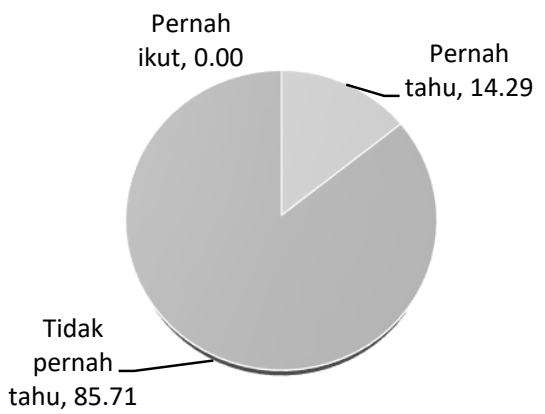

Gambar 1. Tingkat pengetahuan peserta sebelum kegiatan PPMUPT

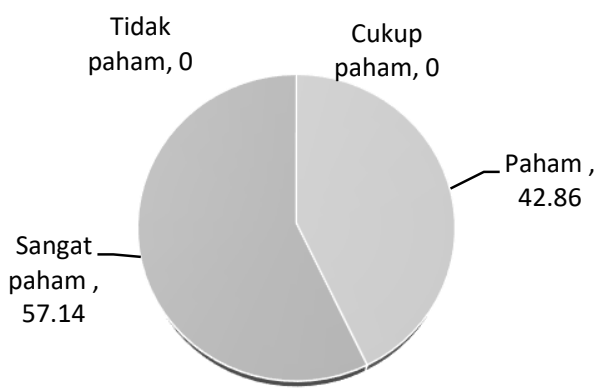

Gambar 2. Tingkat pemahaman peserta sesudah kegiatan PPMUPT

$$
\text { Pendapat peserta tentang }
$$
penggunaan tali ris senar untuk mengganti tali polietilen sebagai tali ris dapat dilihat pada Gambar 3, dimana 35,71\% peserta sangat setuju dan $57,14 \%$ menjawab setuju (total 92,85\%). Peserta yang belum setuju sebanyak 7,14\%. Peserta yang 92,85\% umumnya memberikan alasan bahwa mereka optimis dengan penggunaan tali ris senar akan meningkatkan produksi rumput laut karena dapat mengurangi serangan penyakit. Peserta yang belum setuju $(7,14 \%)$ juga memberikan jawaban yang sama, tetapi alasan belum setuju penggunaan tali senar untuk mengganti tali polietilen sebagai tali ris karena terkendala biaya pembelian tali senar.

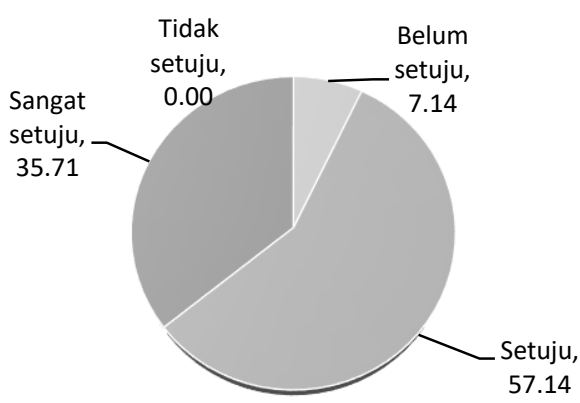

Gambar 3. Tingkat pemahaman peserta tentang penggunaan tali ris senar

Pendapat peserta tentang budi daya rumput laut dengan metode vertikultur sebagai wadah dapat dilihat pada Gambar 4, dimana $28,57 \%$ peserta sangat setuju dan 64,29\% menjawab setuju. Peserta yang belum setuju sebanyak $7,14 \%$. Seluruh peserta pada prinsipnya paham tentang manfaat metode vertikultur sebagai wadah budi daya rumput laut akan lebih efisien dan efektif dibandingkan dengan metode tali rawai permukaan. Peserta yang belum setuju $(7,14 \%)$ memiliki alasan yang sama seperti pada penggunaan tali ris senar, bahkan akan lebih banyak biaya yang dibutuhkan apabila membongkar wadah yang lama kemudian diganti dengan wadah vertikultur. 


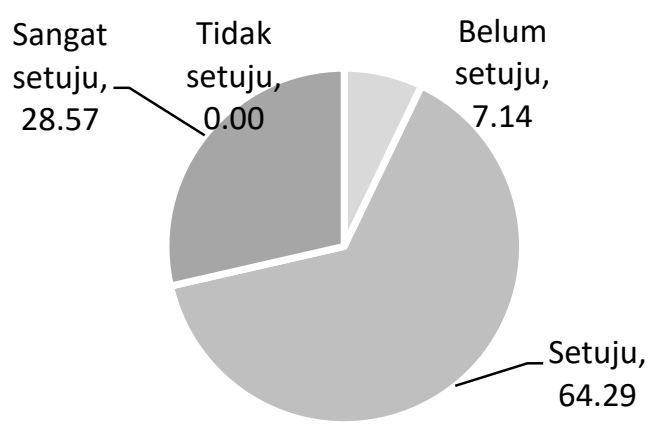

Gambar 4. Tingkat pemahaman peserta tentang wadah vertikultur

Peserta pada prinsipnya puas dengan kegiatan PPMUPT ini, bahkan 92,86 menyatakan bahwa mereka sangat puas dalam mengikuti kegiatan PPMUPT tentang penggunaan tali senar sebagai tali ris dengan metode vertikultur rumput laut. Hal tersebut dapat dilihat dari hasil posttest pada Gambar 5,

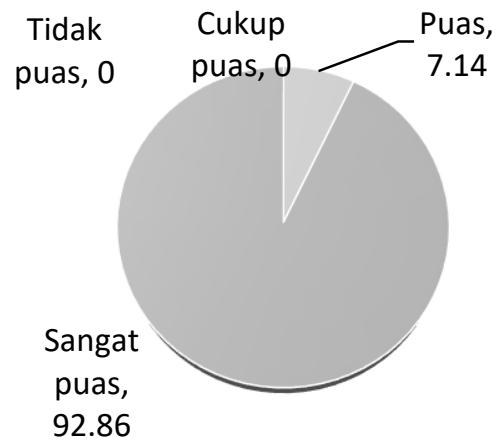

Gambar 5. Tingkat kepuasan peserta tentang kegiatan PPMUPT

Pelaksanaan program PPMUPT ini, untuk hal-hal yang bersifat prinsip dilakukan pendekatan konsultatif terhadap peserta. Kelompok Mitra sebagai peserta diminta pendapat-pendapatnya serta diberitahu atau diluruskan pendapat yang keliru atau menyimpang. Kegiatan praktek di lapangan dilakukan pendekatan partisipatif, dimana bersama peserta membahas tentang permasalahan, mencari alternatif pemecahan masalah, kemudian membuat keputusan secara bersama-sama (Gambar 6).

\section{KESIMPULAN}

Permasalahan budi daya rumput laut di Pulau Nain solusinya dapat dilakukan dengan mengaplikasikan hasilhasil riset budi daya rumput laut yang sesuai dengan urgensi kebutuhan masyarakat.

Penguatan potensi budi daya rumput laut di Pulau Nain ditunjukkan dengan sangat antusiasnya peserta dalam mengikuti seluruh kegiatan. Peserta yang telah memiliki pengetahuan dan pengalaman mengenai budi daya rumput laut sangat mudah memahami materi ceramah dan praktek.

Kegiatan PPMUPT ini sangat berhasil karena terjadi peningkatan pengetahuan di atas $60 \%$ tentang penggunaan tali senar sebagai tali ris dengan metode vertikultur rumput laut dibandingkan sebelum pelaksanaan PPMUPT.

\section{UCAPAN TERIMA KASIH}

Kegiatan Program Pemberdayaan Masyarakat Unggulan Perguruan Tinggi (PPMUPT) ini dibiayai oleh Direktorat Riset dan Pengabdian Masyarakat, KEMENRISTEK DIKTI melalui LPPM UNSRAT. 


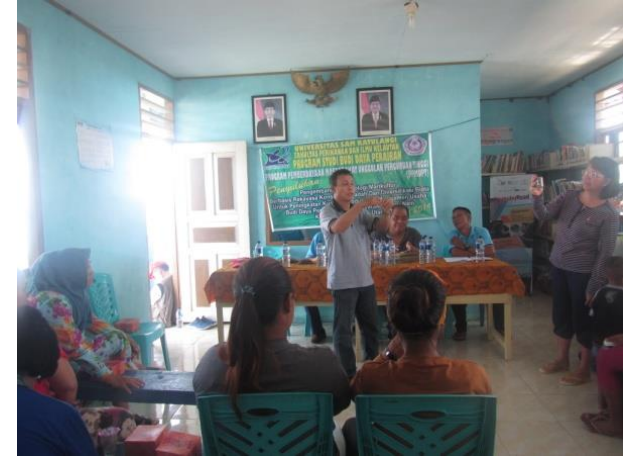

a. Penyuluhan teori di kelas

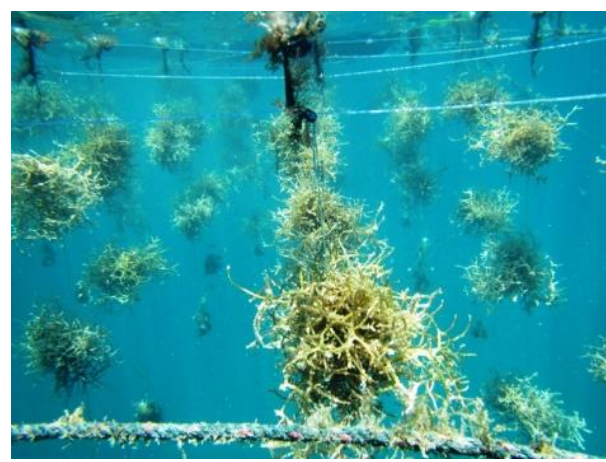

c. Hasil wadah budidaya terpasang

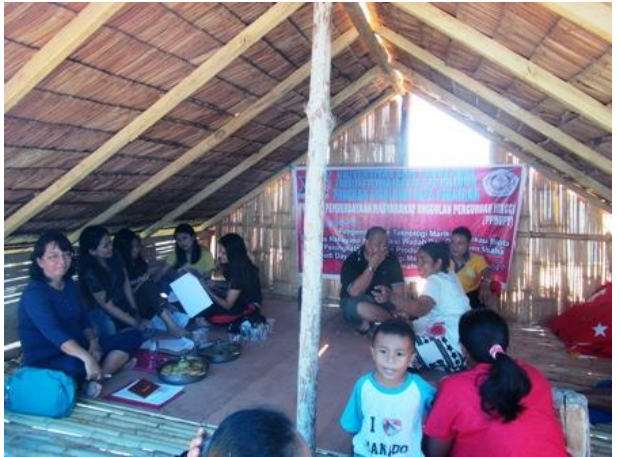

b. Penyuluhan praktek di lapangan

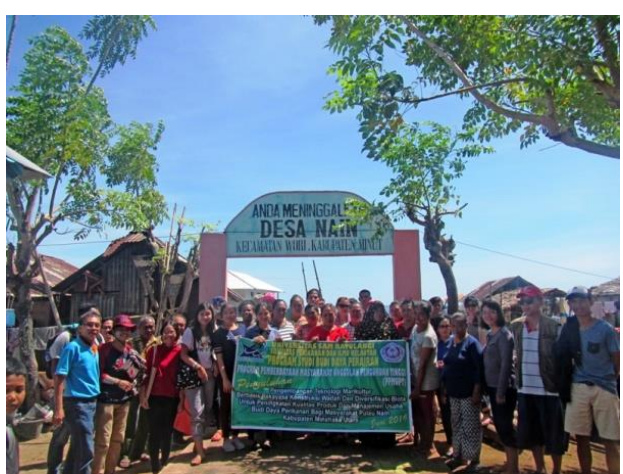

d. Foto bersama pelaksanaan PPMUPT

Gambar 6. Dokumentasi kegiatan PPMUPT di Pulau Nain

\section{DAFTAR PUSTAKA}

Gerung GS, Longdong SNJ, Tumbol RA. 2018. Ko-kultivasi rumput laut Kappaphycus alvarezii dan ikan nila laut. Laporan Penelitian. Skim RTUU. LPPM Unsrat. Manado.

Hadi SN, Rahayu AY, Widiyawati I. 2017. Penerapan Teknologi Berkebun Sayur secara Vertikultur pada Siswa Sekolah Dasar di Purwokerto, Jawa Tengah. Jurnal Panrita Abdi 1(2): 114-119.

Kreckhoff RL, Undap SL, Ngangi ELA, Kusen DJ. 2018. Uji efektifitas ekstrak kasar sebagai sumber imunostimulan dari alga Kappaphycus alvarezii yang dikultivasi pada tiga sentra produksi rumput laut di Sulawesi Utara. Laporan Penelitian. Skim PDUPT.
DRPM Kemenristekdikti. LPPM Unsrat. Manado.

Ngangi ELA, Gerung GS, Mudeng JD. 2018. Rekayasa Desain Dan Material Konstruksi Wadah Kultivasi Rumput Laut Secara Vertikultur Guna Peningkatan Hasil Produksi Perikanan Marikultur Di PulauPulau Kecil. Laporan Penelitian. Skim PSNI. DRPM Kemenristekdikti. LPPM Unsrat. Manado. 